\title{
Urban projects, sustainable development and participatory democracy. Opportunities and limitations - Introduction to the special issue
}

\section{Jean-Bernard Racine, Lausanne}

Contemporary geographers generally conceive the range of territories and landscapes as an expression of a dialectical relation between the social and the spatial; the result of human shaping of the environment in accordance with a project stemming from a set of values and traditions, as well as cultural, social, and political attitudes. In short, these spaces are seen as products of the ideology in which each society is grounded. Ultimately, geographers see the world as being the expression of the way societies use their freedom and geography as the study of the conditions that make possible the concrete and collective realization of such freedom, taking historical, natural, social or institutional constraints into consideration.

Through its system of direct democracy, referendums and initiatives, Switzerland, for example, appears to offer its citizens a great amount of such freedom. A closer look, however, shows that this system of direct democracy is largely conditioned and even manipulated by agents that completely elude ordinary citizens, most notably when it comes to transformations that affect the places they live in. «Participatory democracy» has thus emerged in the last few years as a complement to «representative democracy», supported by the 1980 Federal Law on Land Management.

This thematic issue builds on the two notions of participatory and representative democracy and interprets them through a critical examination of diverse examples of urban participatory democracy. Referring to the example of Switzerland again, Swiss law stipulates that authorities should «ensure that the population can adequately participate in establishing plans» (own translation) (Loi sur l'aménagement du territoire LAT, art. 4, al. 2). As ZuPPINGER (2008: 29), a Lausanne urban planner, rightly points out in an article on the role of participation in the institutional context of land management in Switzerland, this stipulation could mean many things: «according to jurisprudence, <participation> can mean inform, consult or substantially involve citizens in finding solutions» (own translation).

Nonetheless, following trends to be seen in urban development in Switzerland, it would appear that the legitimacy of urban governments depends on their ability to define new stakes, a new style of public action and a means of governing through the participation of citizens in urban projects (SÖDERSTRÖM et al. 2000; SöDERSTRÖM 2007). The suitability of the participation process as a means of achieving a local consensus in the invention and production of urban development is critically examined herein, particularly with reference to its ability to link quality of life to social balance under the very general label of urban sustainable development. Besides institutional actors, citizens and professionals, such as geographers, architects, consultants and cultural programmers, several new actors have joined the participatory process. This thematic issue is therefore composed of a series of contributions from a wide range of specialists who bear witness to recent developments.

In the commentaries at the end of the issue, a remarkable recent publication by JEAN-PIERRE GAUDIN (GAUDIN 2007) is briefly presented. In his book, GAUDIN examines the participation process from the perspective of democracy and sovereignty. In particular, he questions whether participation is a suitable solution to political crises. As a researcher who specializes in public policy analysis, he is able to substantially introduce the concept by recasting its emergence within the context of its origins and by clearly interpreting circumstances of the more recent expansion of multiple and diverse references. These recent references all refer to democratization, or its strengthening, between the space of (political) representation and participatory representation, i.e. «representative democracy and participatory democracy» (GAUdIN 2007: 94).

GAUDIN also questions the extent to which participatory democracy and representative democracy can coexist, and even reinforce each other. Can these two democratic modalities be considered at the same level? Is a hybrid form conceivable? Can bridges be built and knowledge be shared between the two? If so, under what conditions, by whom and how? According to what modes and norms, to what aim, at which scale - neighborhood, city? What are the risks associated with such participation? Underlying all these questions is yet another: is what is being witnessed actual potentiality or mere democratic make-believe. Based on examples from Switzerland, France and other neighboring countries, several states in the USA, like California, and in particular, Brazil, GAUDIN's book emphasizes that the discussion cannot be conclusive due to the diversity of contexts. 
The results and discussions presented in the articles in this issue reflect different purposes. They are either part of doctoral dissertations in geography (SÉBASTIEN JACQUOT in Angers and ANTOINE FleURY in Paris), stem from recent geographic research (PAul Villeneuve, University of Laval in Quebec) or result from major critical research on behalf of municipalities (JEANYves TousSAINT - city planner - and SOPHIE VAREILLES - engineer - from the National Institute of Applied Sciences in Lyon). Despite this difference in purpose, the articles allow a transversal, interdisciplinary, and international comparison of a series of experiments from France, Switzerland, Italy, Scotland, and Chile.

Thus, according to the sociologist, MatThIAS DriLling, sustainable urban development appears to build on both the valorization of public spaces and on major architectural and urban projects. He links participation to a particularly relevant theoretical framework by looking at urbanization regimes, conceived as forms of long-term coalitions which inspire actors to invest resources and competences in local networks. Use is made of examples of sustainable neighborhoods in Geneva, Lucerne and Basel. The examples include particularly innovative projects in areas such as wastelands and unused railway grounds, and by integrating start-ups into sustainable goals. Such projects are innovative in three ways: context sensitivity, integration of minorities as well as adherence to sustainable development principles.

All of these interdisciplinary examples feed the active, prospective and imaginative reflection among urban geographers. Ultimately, they bear witness to the extraordinary conceptual and theoretical richness linked to the process and evolution of both human representations and understanding of human urban practices. With reference to public spaces and local democracies in Paris, Fleury shows how a new urban culture has progressively taken root, and how what was previously considered a mere circulation space, a technical and functional object, is now a «public space», a mediation space, a vector of social life, a space of values, indeed, a «public landscape» and a symbol and sign of urban culture. He highlights how a relationship was established between a public-space crisis and a democratic crisis. He argues that such crises may be resolved by turning to a participatory process to allow a mobilization of civil society. Such a mobilization evidently calls for the realization of certain conditions to ensure that the interests of the majority are met.

According to JACQUOT, participation is a polysemic category of public action. JACQUOT argues that the new tools of citizen participation in urban policies are linked to the emergence of a new «participatory paradigm». He explores whether the different manifesta- tions of participation refer to what he terms «urban regulation within the context of urban and heritage projects» (own translation). JACQUOT offers two, on the surface strikingly different, examples to underlie his argumentation: Genoa and Valparaiso. His analysis of modalities of collective action integrated into public action bring him to similar conclusions as GAUDIN: one of the major questions stemming from the process is that of project legitimacy and the ability to formulate projects so that participation aims at allowing citizens to influence urban land management. He compares two categories of participatory processes: those conducted by public authorities, implying a prior definition of land management principles, and those stemming from opposition processes. He argues that a plurality of expertise and an axiologic dimension are necessary for participation to influence public policies.

Who profits from concertation? JEAN-Yves TousSAINT and Sophie Vareilles, from the National Institute of Applied Sciences in Lyon respond as follows: «Can we think of it in a relevant and useful way?» (own translation). Thus they formulate a doubt that the concept can be looked at in a relevant and appropriate way. The article carefully explores concertation in projects aimed at requalifying urban public spaces, profiting from an insider perspective of experiences made in Lyon. It presents a critical typology of the concertation tools used in Lyon, in terms of communication, knowledge and implication, gauged on the basis of announced democratic promises. They highlight that despite the good faith of those they call «manufacturers of tools who, taken together, build urban infrastructures», i.e. «the technical and spatial tools of the city» (own translation), despite the good faith of those citizens who participate in the process, despite the increase in interaction between these two sets, and despite all the effort taken to ensure real participation and influence of citizens,

«within this social and political order use of an infrastructure is not the aim of production; it is its consequence. From this perspective, objects are not made necessary by their use; rather, objects impose a use and may even define possible uses through their functioning. It is this subordination of use to function that makes concertation necessary» (own translation).

In other words, successful urban concertation would be tantamount to the completion of a project without any opposition from the public or with their partial or total adhesion. «Concertation conceived of as the taking into consideration of use has as its main aim the performance of management» (own translation). This is so because «the meaning given by users to manufactured objects eludes manufacture» (own translation). The article argues for concertation to be considered 
as a subordination of urban use to urban form. In the process, urban action is instrumentalized. This observation is documented both in terms of the arguments supporting it and of the empirical observation of discourse and practice. Concertation thus appears to be «counter-productive in terms of urbanity and more generally of civility» (own translation), in that it seeks first and foremost the performance of the construction process. This is a far cry from the freedom proclaimed by the concept.

Nevertheless, can participatory urbanism, or at least the generalization of public debate, be seen as an element of sustainable urban development? The former President of Canadian Geographers, Paul Villeneuve, and his young colleagues, CATHerine Trudelle, Mathieu Pelletier and Florent Joerin, ask this question with reference to central neighborhoods in the city of Quebec. Over the last few years, these neighborhoods have become places for experimenting with urban and citizenship debates. Consequently, the city targets projects that aim at strengthening the new urbanity of the provincial capital. The process is simple, albeit original and new: to identify and relate indicators capable of helping researchers to evaluate co-variations between levels of urbanity and the vigor of development participatory and public debates at the level of neighborhoods. Urbanity is defined by demographic growth and degree of gentrification, the latter being defined as the differences in land income between suburban and central neighborhoods. Vigor of debates is measured through an analysis of press coverage of conflicts and controversies. Thus, use is made of a quantitative model and qualitative arguments. The conclusion is drawn here that the political process is more important than purely economic mechanisms, related, for instance, to the nowadays classic rent-gap hypothesis. The authors emphasize though, that the effects of local democratization together with this process of public consultation could be questioned by the elitist regime of governance through projects that have been taking root under the new city administration.

\section{What about Lausanne? The «Métamorphose» project: giving citizens a voice}

In 2008, the municipality of Lausanne put together a committee in charge of the very complex «Metamorphosis» project, a project approved by the population following a test in representative democracy, a central element of the 2006 legislature. The author of this article was one of those committee members. The project followed a major poll on the needs and hopes of the population that had been conducted within the Agenda 21 process and explicitly targeted sustainable development involving the population.
Upon signing the Aalborg Charter in 1998, the Lausanne municipality pledged to implement a sustainable development program through its Agenda 21. With this in mind, politicians and members of think tanks loosely linked to mostly green and left-wing members of the city legislature, encouraged the municipality to initiate a first participatory process, termed «Quartiers 21» («Neighborhoods 21») and presented as a model of partnership governance. More than 1'000 people participated in the process, and in each neighborhood citizens had the opportunity to formulate their wants and needs on a variety of topics. The process was divided into three phases: innovation workshops, consensusbuilding conferences and finally, an assessment by the city authorities.

The goal was therefore to let ordinary citizens voice their desires. The citizens were given no particular training in the topics that were being discussed, the discussions were carried by their manifest interest and their active and reflexive will. The project had its limits. Participants were not necessarily representative of the population, neither in terms of age and origin, nor in terms of years spent in their neighborhood. Moreover, the number of participants declined as the process entered its second phase - consensus-building. The goal of this phase would ultimately eliminate potentially interesting contradictions and innovative ideas. Technically and legally, the process suffered multiple flaws (RACINE 2006). This first experience nonetheless brought to light a series of needs: learning how to live together, accommodation, sustainability and security. These results were analyzed in light of more theoretical imperatives stemming from the familiarity of members of the municipality and their services with the literature, as well as imperatives of density, mixity, proximity and mobility, and, most notably, the urban development orientation deemed necessary in terms of public transit.

The Metamorphosis project is structured around four highly related and complementary components (RACINE 1999, 2007, 2008). One of these meets the urgent need to deal with the apartment crisis that affects the city, by planning a new neighborhood in the low-density northern part of the city, in what is called the Blécherette plateau. This neighborhood is defined as having «great environmental value» and meets the criteria of an ecologically and socially sustainable development. To allow its construction, the 1954 Olympic Stadium - currently in bad shape and difficult to renovate - needs to be torn down. The new «eco-neighborhood» includes more than 2'500 apartments and fulfills standards of density and mixity, both in terms of social and intergenerational characteristics, and functional mobility and proximity. In connection with the new neighborhood, a new public transit 
line following the recent M2 subway line is planned. The new line is to be financed to maximum $40 \%$ by the Federal Government. Sports infrastructure is to be modernized and further developments targeted at hosting both small, popular events and major events are planned in the northern part of the city. New infrastructure is also foreseen for the southern part of the city - a new football stadium and an Olympic swimming pool, the latter being on the waiting list of the «Olympic Capital» for many years. All these projects are to be made possible through public-private partnerships and through their integration into a large, coherent, and balanced (most notably in financial terms) urban project.

What remains unknown is how this new urban project will become part of a mostly crystallized urban history, and what spatial and socio-political dynamics are to be expected, considering that until recently they had seemed rather lethargic. It may also be assumed that the proposed model is likely to create new problems as it solves current problems. This can already be seen in the at times violent reactions of residents challenging different components of the project, be these relocation, creation, or participation. A communal initiative, launched by a group of residents and supported by a few specialists, was aimed at preserving the interests of the Northern part of the city This group not only opposed the project right from the beginning, but also refused to participate in the process by systematically boycotting any initiative related to it. The consequence was that the professionals were forced to work on the project alone and the authorities had to modify the modus operandi. Thus, the relevance of cooperation between expert and layman is questioned.

\section{A different Metamorphosis? An ambiguous contestation}

Metamorphosis was meant to be tailored to each particular project whilst simultaneously initiating a major development and redistribution of the sports infrastructure and creating an eco-neighborhood with high environmental value, linked to the creation of a new public transit backbone. The project was thus contributing to further city densification. It also challenged several well-entrenched habits and socio-affective valorizations of a whole neighborhood because it entailed the demolition of an Olympic Stadium - the last one of its kind in Switzerland and of urban heritage status. As initial major geographic options were declared «non-negotiable», some inhabitants decided to boycott the participatory process. A communal initiative was thus launched (a first in the Vaud canton), inviting citizens to reject the project and proposing a «different Metamorphosis», one that would keep the sports infrastructure in the North and build the eco-neighborhood in the South. The ensuing theoretical and practical debate was long and harsh and addressed various issues: geographic, social, economic and related to urban planning.

Supporters of the municipality's project saw in their opponents' reaction a traditional suspicion towards change, and a NIMBY (Not In My Backyard) attitude; the opposition was an issue of identity, a failing to distinguish between an object and its function (as the old stadium, although a «monument» was often deserted); opposition in general was seen as a failing to understand the benefits of the project. Opponents expressed concerns over the public-private partnership, thus misunderstanding the fact that surface rights given by the city and fiscal revenues would actually benefit the city. Opponents argued that a «ghetto» or a «bedroom suburb» was being built and called for greater attention to mixity and public infrastructure. However, they seemed to oversee the criteria inherent to the development of an eco-neighborhood with the need not only to adhere to ecological principles concerning construction materials, energy, waste, and transport, but also to pay attention to solidarity, social, generational, cultural, and functional mixity, as well as a set of principles related to well-being, culture, conviviality, and heritage conservation. Opponents' reactions were also shared by right-wing parties, the Green party and a few geographers and urbanists who did not agree with a shift of the city from the North to the South.

It should also be recognized that for those who live near the Olympic Stadium, the stadium is more than a stadium; it is a «monument», experienced as part of heritage and invested with a true identity, in spite of all its drawbacks, such as an alarmingly ageing structure, a lack of VIP zones and a - albeit excellent - field surrounded by a track that separates the public and the players. According to WunEnBurger (1997: 204), this effect of the stadium on its neighborhood would be an example of «spatial cognitive meaning» (own translation). The concept refers to the existence of an affective and emotional relation to space i.e. the way a landscape, a city, and the image of it «is felt, is charged with emotions, and initiates feelings» (own translation) (Bochet \& Racine 2002: 128; Bochet 2007: 255), the city initializing something in its inhabitants which resonates in them, an affective phenomenon, ultimately an effect of the world on their sensitivity.

On September 27, 2009, the city's population finely approved the project. $55,7 \%$ of the voters rejected the alternative proposed in the communal initiative, an alternative that would have left the project bereft of its geographic and urban planning meaning. The entire 
process provided a unique opportunity to critically and strategically reflect on the way to lead an urban project and solve possible contradictions between representative democracy and participatory democracy.

The battle of opinions was a reminder that a city is a living system, an evolving space that constantly needs to be reinvented. Mutability means giving urban space the ability to change not only in usage and function, but also in meaning. This is an underlying principle of intelligent urbanism. After a period of urban development that stretched to the city's limits, Lausanne experienced a period of a «return» to the city, a return that aimed at its transformation, not only at its renovation and restoration. The ambition of this transformation is to create new urban configurations based on existing structures, in an ecologically and socially sustainable fashion. Cities are not checkerboards but shifting archipelagoes of appetite. In spite of the difficulties inherent in the cooperation between expert and layman (GAUDIN 2007: 67), developing forms of population involvement in progressively improved participatory democracy (Blondiaux 2007; Felli 2005, 2006; RACINE 2009; SöDERSTRÖM et al. 2000; SÖDERSTRÖM 2007; TousSAINT \& VAREILLES 2006) may convince people that cities are the solution, not only the problem.

\section{Bibliography}

BlondiauX, L. (2007): La démocratie participative, envers et malgré tout. Un plaidoyer paradoxal en faveur de l'innovation démocratique: - In: Mouvements 50:118-129

Bochet, B. \& J.-B. Racine (2002): Connaître et penser la ville: des formes aux affects et aux émotions, explorer ce qu'il nous reste à trouver. Manifeste pour une géographie sensible autant que rigoureuse. - In: Géocarrefour, Revue de géographie de Lyon 77, 2: 117-132.

Bochet, B.(2007): Débat ville étalée - ville compacte: la réponse des projets lausannois. - In: Revue Economique et Sociale 65: 95-108.

Felli, R. (2005): Développement durable et participation: la démocratie introuvable. - In: Belgeo, Revue belge de géographie 4: 425-619.

Felli, R. (2006): Développement durable et démocratie: la participation comme problème. - In: Urbia, Les Cahiers du développement urbain durable 3: 11-28.

Gaudin, J.P. (2007): La démocratie participative. Paris: Armand Colin.

RACINE, J.-B. (1999): Lausanne entre flux et lieux. Vous avez-dit «moyenne». - In: COMMERÇON, N. \& P. GEORGE (eds): Villes de transition. - Paris: Anthropos: 147-186. RACINE, J.-B. (2006): Shaping future together. Participatory research and methods for a socially sustainable urban development. Lessons from the participation in Agenda 21 in Lausanne. - In: LoIs Gonzalez, R.C. (ed.): Urban changes in different scales: systems and structures. IGU Commission on Monitoring Cities of Tomorrow, Cursos e Congresos, no. 169, Santiago de Compostela: Universidad de Santiago de Compostela: 223-236.

RACiNE, J.-B. (2007): Les villes en quête d'urbanité: logiques économiques et sociales. Quelle ville voulonsnous? - In: Revue Economique et Sociale 65:25-34. RACINE, J.-B. (2008): Projet urbain et démarche participative: contribution géographique à la possibilité de choisir sa ville aujourd'hui, quelques leçons de l'expérience lausannoise. - In: Bulletin de la Société géographique de Liège 50:5-15.

RACiNE, J.-B. (2009): Città e democrazia partecipata: le nozze tra esperto e profano. Riflessioni sul possibile coinvolgimento del sapere geografico. - In: UTET Università (ed.): Le frontiere della geografia. Testi, dialoghi e racconti per Giuseppe Dematteis. - Novara et Milano: De Agostini: 129-144.

Söderström, O., Cogato Lanza, E., Lawrence, R.J. \& G. BARBEY (sous la dir.) (2000): L'usage du projet. Pratiques sociales et conception du projet urbain et architectural. - Lausanne: Payot.

Söderström, O. (2007): A Genève et à Lausanne on consulte ou on négocie, mais à Zurich on co-construit. - In: Le Temps, 5 juin 2007, rubrique Opinions.

Toussaint, J.Y. \& S. VAREILlES (2006): La durabilité à l'épreuve des pratiques d'aménagement urbain. Le cas de la concertation dans l'espace public de l'agglomération lyonnaise. - In: Urbia, Les Cahiers du développement urbain durable 3: 61-75.

Wunenburger, J.-J. (1997): Philosophie des images. - Paris: Presses Universitaires de France.

ZuPPINGER, U. (2008): La participation dans le foncier dans l'aménagement du territoire. - In: Urbia, Les Cahiers du développement urbain durable 6: 27-42.

\section{Summary: Urban projects, sustainable development and participatory democracy. Opportunities and limitations}

This special issue introduces different texts on urban participatory democracy, a topic that has recently gained much momentum. The issue allows a transversal, interdisciplinary, and international comparison of a series of experiments from France, Switzerland, Italy, Scotland and Chile. The examples show sustainable development to be as much an element of the valorization of public spaces as of major architectural and urban planning projects. The introduction focuses on a critical description of ongoing projects in the city of Lausanne which bear testimony to the effect citizen participation in urban project development can have in defining new stakes, a new style of public action and a way of governing. This process of participation can lead to a process of cooperative construction of the environment. The article closes with an examination of the ambiguities and flaws inherent in participatory democracy. 
Keywords: participatory democracy, urban projects, participatory urbanism, public spaces, Paris, Lyon, Edinburgh, Genoa, Valparaiso, Basel, Lausanne

\section{Résumé: Projets urbains, développement durable et démocratie participative. Intérêt et limites}

Introduisant l'ensemble de ce numéro thématique au titre de «guest editor», l'auteur présente les différents textes qu'il a pu réunir autour de la thématique aujourd'hui très tendance dans les villes occidentales de l'ouverture à la démocratie participative en matière de projets urbains. Il s'agit là d'une façon de permettre la comparaison, dans une vision transversale, interdisciplinaire et internationale d'une série d'expériences portant aussi bien sur la France, la Suisse, l'Italie, l'Ecosse et le Chili. Les exemples s'appuient tant sur la valorisation des espaces publics que sur des réalisations architecturales et urbanistiques importantes, toutes conçues dans les perspectives du développement durable. La présentation in fine du cas lausannois, en cours de réalisation, témoigne également de la capacité à définir de nouveaux enjeux et un nouveau style d'action publique, comme méthode de gouvernement, par le management de «projets urbains» ou «projets de ville» conçus en collaboration avec les populations concernées et visant, à la limite, par cet urbanisme pratique la réalisation d'un véritable processus de co-construction des espaces de vie. Nouveau mode de faire la ville, l'urbanisme participatif n'est pourtant pas sans ambiguités et sans faiblesses, ce que l'article tente de mettre en évidence de manière réflexive et critique.

Mots-clés: démocratie participative, projets urbains, urbanisme participatif, espaces publics, Paris, Lyon, Edinbourg, Gênes, Valparaiso, Bâle, Lausanne

\section{Zusammenfassung: Urbane Projekte, nachhaltige Entwicklung und Partizipationsdemokratie. Nutzen und Grenzen}

Als Gast-Herausgeber des vorliegenden Themenheftes stellt der Autor verschiedene Texte zum Thema der städtischen Partizipationsdemokratie vor, ein Thema, das in letzter Zeit grosse Aufmerksamkeit auf sich zieht. Die Beiträge ermöglichen einen transversalen, interdisziplinären und internationalen Vergleich einer Reihe von Erfahrungen aus Frankreich, der Schweiz, Italien, Schottland und Chile. Beispiele nachhaltiger Entwicklung gründen sowohl auf der Aufwertung öffentlicher Räume als auch auf massgeblichen architektonischen und urbanistischen Projekten. Die Einleitung fokussiert auf einer Beschreibung aktueller Projekte in Lausanne, die von der Fähigkeit zeugen, neue Ziele, einen neuen Stil öffentlicher Aktion sowie eine Regierungsweise, die durch die Partizipation der Bürger bei der Entwicklung urbaner Projekte gekennzeichnet ist und möglicherweise zu einem Prozess kooperativer Konstruktion der Umwelt führt, zu definieren. Partizipationsdemokratie ist jedoch nicht frei von Mehrdeutigkeiten und Schwächen, die dieser Beitrag auf reflexive und kritische Art aufzuzeigen versucht.

Schlüsselwörter: Partizipationsdemokratie, städtische Projekte, partizipatorischer Urbanismus, öffentliche Räume, Paris, Lyon, Edinburg, Genua, Valparaiso, Basel, Lausanne

Prof. Dr. Jean-Bernard Racine, Faculté des Géosciences et de l'Environnement, Amphipôle, Université de Lausanne, CH-1015 Lausanne; Avenue du Grey 16, CH-1004 Lausanne, Switzerland. e-mail: Jean-Bernard.Racine@unil.ch 